\title{
Notes
}

\section{The Dual Role of the Structural Injunction}

\author{
Robert E. Easton
}

The structural injunction ${ }^{1}$ developed as a means to assist judges ${ }^{2}$ in effecting the mandates of desegregation decrees. Over the last thirty years, judges have used structural decrees to reform penal institutions, ${ }^{3}$ administer mental hospitals, ${ }^{4}$ reform the racial composition of schools, ${ }^{5}$ guide en-

1. The "structural injunction" remedy is actually a hybrid, partaking of several remedial devices selected and assembled by the judge to implement declared rights. This hybrid may consist of receiverships, selected and assembled mandated policy reforms, continuing judicial supervision, informationgathering, and various types of dispute resolution outside of the courtroom. Its general purpose

is to alter broad social conditions by reforming the internal structural relationships of government agencies or public institutions. Instrumentally, it operates through the forward-looking, mandatory injunction but assumes a relatively intrusive form, a more or less detailed order whose prescriptions displace significant areas of defendants' discretion. It relies upon a rather fluid, group-oriented party structure and often demands an active, administrative role for the judge. It usually finds its justification in the more open-ended constitutional provisions, such as the equal protection or due process clauses. Its issuance often precipitates an extremely protracted process typically including judicial wheedling, spasmodic negotiation, and bureaucratic resistance.

P. Schuck, Suing Government: Citizen Remedies for Official Wrongs 151 (1983).

2. Professor Abram Chayes observed that the job of the Federal judge has changed radically since the turn of the century, noting the triumph of the public law litigation model over the "received tradition" of the lawsuit as a dispute resolution mechanism between private individuals. Chayes, The Role of the Judge in Public Law Litigation, 89 HARv. L. REv. 1281 (1976). The new conception is marked by the fact that "lawsuits do not arise out of disputes between private parties about private rights. Instead, the object of litigation is the vindication of constitutional or statutory policies." Id. at 1284.

3. See infra note 62 (citing cases); see also Jones, Federal Court Remedies: The Creative Use of Putritial Remedies Can Produce Institutional Change, 27 How. L.J. 879, 880 n.3 (1984) (examples of prison reform efforts).

4. E.g., Wyatt v. Stickney, 344 F. Supp. 373, 344 F. Supp. 387 (M.D. Ala. 1972), enforcing 325 
vironmental protection efforts, ${ }^{6}$ and establish public housing policy. ${ }^{7}$ The results of such efforts have been mixed, and critics have charged that the decree impermissibly or imprudently expands the role of the judge. These critics focus on the structural injunction's typically far-reaching and unforeseen effects, ${ }^{8}$ the limitations of the judge as policymaker, ${ }^{8}$ and the problems that the judge encounters in overcoming bureaucratic resistance. ${ }^{10}$ Proponents of the decree focus on a number of related justifications, most of which center on the need for the judge to ensure that constitutional values are not abridged by administrative bodies.

This debate, however, has focused on the role of the judge in a structural decree rather than on the role of the bureaucratic institutions ${ }^{11}$ at the center of the reform efforts ${ }^{\mathbf{1 2}}$ and on the interplay between judge and bureaucracy. While scholars of administrative law have analyzed the relationship between bureaucratic agencies and the political bodies that oversee them, ${ }^{13}$ insufficient attention has been paid to the unique ways in

F. Supp. 781, 334 F. Supp. 1341 (M.D. Ala. 1971), affd in part, remanded in part, decision reserved in part sub nom. Wyatt v. Aderholt, 503 F.2d 1305 (5th Cir. 1974) (Constitution guarantees right to minimal standards of care and treatment to institutionalized mentally retarded persons and to committed mental patients); see also Note, The Wyatt Case: Implementation of a Judicial Decree Ordering Institutional Change, 84 Y ALE L.J. 1338 (1975) (examining role court can play in institutional reform).

5. E.g., Swann v. Charlotte-Mecklenburg Bd. of Educ., 431 F.2d 138 (4th Cir. 1970) (en banc) (affirming court-ordered busing plan), aff d, 402 U.S. 1 (1971).

6. E.g., United States v. Reserve Mining Co., 380 F. Supp. 11 (D. Minn. 1974); see also Henderson \& Pearson, Implementing Federal Environmental Policies: The Limits of Aspirational Commands, 78 Colum. L. REv. 1429, 1453-56 (1978) (discussion of subsequent history of case).

7. E.g., United States v. Yonkers Bd. of Educ., 635 F. Supp. 1577 (S.D.N.Y. 1986) (ordering housing desegregation), 635 F. Supp. 1538 (S.D.N.Y. 1986) (ordering school desegregation), both orders affd, 837 F.2d 1181 (2d Cir. 1987), cert. denied, 486 U.S. 1055 (1988).

8. See Leubsdorf, Remedies for Uncertainty, 61 B.U.L. Rev. 132, 138 (1981) (discussing court's "inability to perceive the consequences of its measures and the details of its goals").

9. In a celebrated essay Professor Fuller expressed concern over the inability of courts to handle "polycentric" tasks, that is, those restructurings which may affect parties difficult to foresee, and he questioned whether judges should engage in this process at all. Fuller, The Forms and Limits of Adjudicalion, 92 Harv. L. Rev. 353, 394-404 (1978); see also D. Horowitz, The Courts and Social. Pourcy 33-56 (1977) (discussing attributes of adjudication and arguing that "courts have very limited ability to monitor and control unintended consequences").

10. See Note, Implementation Problems in Institutional Reforn Litigation, 91 Harv. L. Rev. $428,432-35$ \& n.21 (1977) (discussing organization theory and institutional reform).

11. "Bureaucracy" here is used in the broad sense of an organizational form that receives its authority from an external political source and which must organize people and interests to produce an outcome. This definition therefore includes not only state and Federal administrative agencies, but also other institutions at which the structural injunction is frequently directed, such as prison administrations, school boards, and mental hospital administrations.

12. A handful of observers have noticed the unique characteristics of bureaucracy in structural reform. See, e.g., P. ScHuck, supra note 1, at 123-46 (identifying ways in which public organizations may be responsive to liability); Note, Judicial Intervention and Organization Theory: Changing Bureaucratic Behatior and Policy, 89 YALE L.J. 513 (1980) (arguing that judges must appreciate dynamics of institutional organization to secure change in bureaucracy). However, most commentators who discuss the role of the judge in the context of bureaucratic change limit their discussion to traditional, removed modes of judicial involvement-attempts to reform agency practice, procedure, and policy through more commonly used methods of judicial review of bureaucratic decision-making. This Note, on the other hand, analyzes the structural injunction as a means to examine instances of intricate involvement of a judge in the inner workings of bureaucracy.

13. Of central importance is the seeming ability of legislative and executive bodies to delegate a 
which the judicial branch can shape bureaucratic policy and implementation beyond the traditional means of judicial review.

This Note proposes a framework in which a close analysis can be made of the dynamics of the structural decree. The framework not only illuminates the strengths and weaknesses of structural reform efforts in the past, but also demonstrates the extent to which the goal of bureaucratic legitimacy and responsiveness requires the institution of structural decrees. In this framework, the goal of bureaucratic accountability serves two purposes. First, the decree legitimates bureaucratic policy by defining more clearly the bureaucracy's purpose. The judge may accomplish this either by encouraging the officials to internalize constitutional or statutory requirements, or by forcing them to clarify the general mandates that guide the agency. This "policy level" function includes discussion among the branches of government with the goal of leading politicians to accept a conception of the bureaucracy's purpose consistent with constitutional imperatives. Second, the decree may command the bureaucracy to perform certain tasks or to reshape its functioning according to specific guidelines. In this way the judge ensures the implementation of reforms in accordance with statutory or constitutional mandates. This "street level" aspect of the decree comprises the specific instructions, reforms, and penalties directed toward bureaucratic agents.

Focusing both on legitimation and implementation, this dualistic conception of the structural injunction helps to explain the successes and failures of past structural reform efforts. Past decrees show that specific, street-level directives instructing officials to behave in certain ways are ineffective at achieving the legitimating function of generating consensus on the purpose of the administrative body, but are relatively successful at achieving specific reforms within an institutional setting. Damage-based remedies, on the other hand, will often force clarification of an institution's legitimacy and purpose, but at the cost of not guaranteeing the street-level implementation of necessary reforms.

Part I of this Note outlines three characteristics of bureaucracy in the administrative state that define its relationship to political oversight and to the citizens it serves. Part II reviews two contemporary conceptions of the judge's role in institutional reform and advances a "regulatory theory" of the structural decree in which the structural decree serves as a tool to prevent bureaucratic characteristics from obscuring the twin goals of legitimation of a regulatory institution and implementation of accepted policy

great deal of power and discretion to administrative entities which are not under popular control. While the non-delegation doctrine once helped to constrain the amount of power that could be afforded such bodies, in recent years the courts have consistently upheld the power of Congress to delegate large amounts of administrative discretion to bureaucratic agencies. Proponents of delegation also contend that administrators sometimes require large amounts of discretion to be effective and that such administrators in fact rarely abuse their power. 
directives. Part III applies the model to specific areas of bureaucratic reform and examines two examples of the structural decree.

\section{The Administrative State and the Role of the Judge}

Three defining features of bureaucracy in the modern administrative state are bureaucracies' responsibility for provision of an unprecedented amount of goods and services, ${ }^{14}$ the frequent lack of clear direction provided through executive and legislative channels, and the unique problems with responsiveness that impede a bureaucracy's adaptation to new directives. The first two factors threaten to limit the vision or willingness of administrative actors to perceive the full expanse and the necessary limits of their authority, and the third may limit the effectiveness of the bureaucracy's ability to carry out its mandate.

\section{A. Delivering the New Property}

Since the 1930's, citizens have become far more dependent on bureaucracies at all levels of government for provision of goods and services. This shift away from the provision of many essential needs through individual effort or through the mechanism of voluntarism to provision by government is remarkable not only for the increased pressure that it has put on government resources, but also for the level of dependence that many people now place on the government ${ }^{15}$ for provision of these services and goods. ${ }^{16}$ Furthermore, through licensing requirements and other methods of pervasive government regulation, citizens have become heavily dependent on the government as a means of ensuring their livelihood. This increased dependence reflects an important shift in the role of government

14. This provision of services is described as the economic "public goods aspect" of the regulatory state. See, e.g., Steiner, Public Expenditure Budgeting, in The Economics of Public Finance 248-57 (1974) (detailing different types of public goods).

15. Charles Reich recognized this increased dependence in 1964 when he wrote about the "new property." Reich, The New Property, 73 Yale L.J. 733 (1964). Reich concluded that "government largess will necessarily assume ever greater importance as we move closer to a welfare state. Such a state . . . undertakes responsibility for the well-being of those citizens who . . . cannot provide minimum care, education, housing, or subsistence for themselves." Id. at 738.

Although monetary expenditures are one example of the form that government largess takes, government bureaucracy also provides for people's welfare by arranging institutions, rights, and responsibilities to enhance the welfare of citizen groups. Reich noted this trend by observing that "more and more of our wealth takes the form of rights or status rather than of tangible goods." Id. Reich saw that the largess controlled by government-and issuing from all levels of government, not only Federal sources-is "magnified" when under the control of an administrative agency because the agency typically enjoys broad discretion as to how to distribute the largess. Id. at 749 ("Broad as is the power derived from largess, it is magnified by many administrative factors when it is brought to bear on a recipient.").

16. Estimates of dependence on the state are inherently difficult to make, given the pervasiveness and non-quantitative nature of much government intervention. While the growth of Federal expenditure on public welfare is frequently exaggerated, the national government did grow by approximately $100 \%$ (relative to gross national product) from the 1940 's to the present. G. RoBINSON, E. GELLHORN \& H. Bruff, The Administrative Process 6-7 (3d ed. 1986). To this must be added the roles of state and local governments, institutions which are frequently the object of structural decrees. 
from its previous position as essentially a "watchdog" over the functioning of private markets to an active provider of goods and services. ${ }^{17}$

The danger that judges must guard against in this context is administrators' unwillingness to exercise authority broadly enough to guarantee fair distribution of entitlements. Something like "reverse delegation," this involves administrators' unwillingness to exercise authority to the extent permitted or required by legislation or the Constitution. In most cases, this is because administrators fail to recognize the broader social concerns within which their bureaucracy operates, a job for which the judge is especially well suited. ${ }^{18}$ The judge sees the statutory framework within a broader constitutional vision, defines more precisely than do legislators the contours of constitutional rights, and is in a better position than legislators to evaluate the effects of administrators' decisions on citizens.

\section{B. Discretion of Administrative Bureaucrats}

At both the state and Federal levels, agencies typically enjoy large amounts of discretion in how they exercise their delegated grants of power. The organic statutes of many administrative agencies and the substantive grants under issue-specific laws are sometimes drafted in broad

17. At one time many such goods and services were held to be "discretionary," since Congress' provision of them required intrusions into the sphere of private market tranactions into the sphere of private market transactions conceived of as inviolable. This was part of the Lochner legacy. Lochner v. New York, 198 U.S. 45 (1905). Ackerman, Constitutional Politics/Constitutional Law, 99 YaLE L.J. 453 (1989), provides an explanation of how the New Deal justices repudiated Lochner.

The constitutional revolution of the 1930's not only empowered government to remedy economic and social injustice. It amounted to nothing less than the repudiation of something called a "natural law" philosophy-whose taint, apparently, can be detected in any suggestion that the Founders had not merely tried to codify a list of rules but to formulate principles of personal liberty that modern Americans may still find relevant in a host of non-market contexts. Id. at 543-44; see also Fallon, Of Legislative Courts, Administrative Agencies, and Article III, 101 Harv. L. Rev. 915, 925-26 (1988) (New Deal redefined relationship between Article I and Article III bodies). See generally Sunstein, Lochner's Legacy, 87 Colum. L. REv. 873 (1987); Sunstein, Constitutionalism After the New Deal, 101 HaRv. L. REv. 421, 422-25 (1987) (discussing New Deal's broad theoretical changes in social and economic policy through government redistribution of wealth and creation of entitlements). Many government-provided goods and services-for example, schools and school transportation, care for the elderly and for the mentally disabled, subsistence public housing-have been determined to be an entitlement of the recipients of such services. See, e.g., Goldberg v. Kelly, 397 U.S. 254 (1970) (providing important new procedural checks for recipients under the Aid to Families with Dependent Children program); see also Holmes v. New York City Hous. Auth., 398 F.2d 262 (2d Cir. 1968) (requiring ascertainable standards for allocation of public housing units).

18. This is not to say that this value clarification is the exclusive domain of the judge. Certainly, ather branches of government are competent to make certain determinations about the rights of citizens to receive governmental services. In the domain of basic entitlements, the courts, however, possess a special competence that entitles them a privileged role. See generally Fiss, The Supreme Courl 1978 Tern-Forru'ord: The Forns of Justice, 93 HARv. L. REv. 1 (1979) (arguing for special ability of judges to define society's constitutional priorities). Reich pointed out that in light of the increased dependence of citizens on government, special care must be paid to avoid erosion of liberties:

Government largess, like all wealth, must necessarily be regulated in the public interest. But regulation must take account of the dangers of dependence, and the need for a property base for civil liberties. Rightly conceived, the public interest is no justification for the erosion of freedom that has resulted from the present system of government largess.

Reich, supra note 15, at 777 . 
language. ${ }^{19}$ At one time the Supreme Court insisted that such grants of authority were simply too broad and that they delegated excessive legislative power. ${ }^{20}$ Today, such broad grants of power are common at both the state and Federal levels.

Legislative bodies do, of course, retain the power to revise, amend, further specify, or otherwise limit the discretion that agencies enjoy. ${ }^{21}$ In most cases, however, such revisions leave the agency with as much discretion after the "limitation" as before, ${ }^{22}$ and thereby do little to reduce the room for manipulation and arbitrariness inherent in bureaucratic policy implementation. Administrators therefore retain a great deal of room to water down, pervert, or simply ignore legislative mandates. ${ }^{23}$ Although delegation often provides the administrative flexibility needed for bureaucracies to function effectively, ${ }^{24}$ the potential for discretion to go awry counsels a form of judicial oversight ${ }^{25}$ that ensures agencies do not exceed

19. Congress occasionally updates organic statutes or passes new limiting statutes to add or subtract responsibilities. Nonetheless, agencies' governing statutes still often resemble patchwork legislative products, with different provisions directed to problems thought significant at different points in time. Many regulatory agencies are governed by such statutes. E.g., Federal Communications Commission Act, 47 U.S.C. $\$ \S 151-757$ (1982 \& Supp. V 1987); see also D. Cofer, Judges, BureauCRATS, AND THE QUESTION OF INDEPENDENCE 56 (1985) (because of inadequate "technical expertise or political acumen" and because knowledge would evolve, "Congress was required to take a leap of faith and permit vast exercises of administrative discretion").

20. See, e.g., Panama Ref. Co. v. Ryan, 293 U.S. 388 (1935) (invalidating $\S 9(c)$ of National Industrial Recovery Act for delegating impermissibly broad legislative powers to President); Schechter Poultry Corp. v. United States, 295 U.S, 495 (1935) (same, with respect to § 3). Justice Cardozo, dissenting in Panama but concurring in Schechter, provided the famous dictum, "The delegated power of legislation which has found expression in this Code is not canalized within banks that keep it from overflowing. It is unconfined and vagrant . . . "Schechter, 295 U.S. at 551 (quoting Panama, 293 U.S. at 440 (Cardozo, J., dissenting)).

21. Whether legislatures should retain more control over the discretion of bureaucracies is an open question; the fact that there is a debate on the matter argues more strongly for close judicial scrutiny. For a recitation of reasons for delegating large amounts of discretion, see Fallon, supra note 17, at 935-37. For the opposite view and for a call for more stringent judicial review of such grants, see T. Lowi, The ENd of Liberalism 297-99 (1969).

22. See Mashaw, Prodelegation: Why Administrators Should Make Political Decisions, 1 J.L. ECON. \& ORg. 81 (1985) (positing "Law of Conservation of Administrative Discretion" for administrative agencies by which "[e]limination of discretion at one choice point merely causes the discretion that had been exercised there to migrate elsewhere in the system").

23. See J. Pressman \& A. Whldavsky, Implementation 175-77 (1984). Pressman and Wildavsky observe that "[s]ince administrative discretion can be used as a cover for arbitrary behavior that is unrelated to policy intentions, some authors feel that the problem of administration is, purely and simply, one of controlling discretion." Their response: "Unless one is willing to assume that policies spring fully armed from the forehead of an omniscient policymaker, discretion is both inevitable and necessary. Unless administration is programmed-a robot comes to mind-discretion can be controlled only by indirect means." Id. at 175 .

24. Professor Mashaw has made the important observation that discretion on the part of administrative bodies is not at all a bad characteristic of government by bureaucracy; in many cases, it is the source of bureaucratic innovation and responsiveness. Mashaw, supra note 22, at 95-100 ("[I]t seems likely that the flexibility that is currently built into the processes of administrative governance by relatively broad delegations of statutory authority permits a more appropriate degree of administrative, or administration, responsiveness to the voter's will than would a strict nondelegation doctrine.").

25. The political branches are frequently unable to ensure such bureaucratic accountability. Because of potentially damaging political consequences, the legislature is often unwilling to review administrative action closely. Legislatures sometimes delegate significant discretion to an administrative organization because of conflicting political priorities involved in addressing an issue, particularly a 
or misinterpret their constitutional or statutory mandates. This is perhaps most important when bureaucratic bodies not frequently in the public eye-such as prisons-are involved. ${ }^{26}$

The Administrative Procedure $\mathrm{Act}^{27}$ and analogous state statutes provide examples of legislative frameworks within which agencies enjoy broad discretion and the judiciary retains an important clarifying role. Under these acts, courts ensure both that agencies respect the legislative mandates and that they respect certain procedural requirements.

A similar level of discretion exists among state-level administrative bureaucracies, which are frequently the target of structural decrees. How prison officials must treat prisoners to meet constitutional minimums and whether local school boards must be concerned about racial distributions of students are questions to which organic statutes or analogous provisions of authority that guide agency behavior give only general guidance.

\section{G. Organizational Behavior}

At least two sources of systemic failure may derail institutional pursuit of a policy goal. ${ }^{28}$ The first is bureaucratic suboptimization, the tendency for officials to pursue goals different from those statutorily mandated. Of-

politically volatile one over which no governmental body has extensive authority. The Supreme Court recognized and countenanced this for a congressional environmental statute in Chevron, U.S.A., Inc. v. National Resources Defense Council, 467 U.S. 837, 865 (1984) (in balancing environmental and economic concerns, "perhaps Congress was unable to forge a coalition on either side of the question, and those on each side decided to take their chances with the scheme devised by the agency"). The executive frequently has the authority to appoint the heads of the administrative bodies, see Humphrey's Executor v. United States, 295 U.S. 602 (1935) (affirming President's right to appoint and remove certain Federal administrative officials), and to oversee operational aspects of the agency such as the budget. This budget power has been described as "the most important" statutory grant of agency control possessed by the executive. G. Robinson, E. Gellhorn \& H. BRufr, supra note 16, at 120 . However, the executive generally cannot take both the broad legitimacy perspective and the narrow implementation perspective in assessing agency performance.

The recent case of Dole v. United Steelworkers, $110 \mathrm{~S}$. Ct. 929 (1990), provides an example of limits to the executive's oversight of agency operation. In an effort to limit regulatory burdens on private industry, the Office of Management and Budget invalidated a broad set of regulations by the Occupational Safety and Health Administration. The OMB argued that the Paperwork Reduction Act, 44 U.S.C. $\$ \S 3501-3520$ (1982 \& Supp. V 1987), designed to limit paperwork burdens on parties complying with Federal requirements, also limited the amount of paperwork an employer had to provide third parties when the employer acted under a Federal regulation. The Court struck down the interpretation, holding that the Paperwork Reduction Act by its terms applied only to Federal forms and paperwork required of private parties for compliance.

26. See S. Martin \& S. Ekland-Olson, Texas Prisons: The Walls Came Tumbling Down (1987) (tracing history of prison abuse and reform in Texas). State-level bureaucracies are often the worst offenders of Federal constitutional rights, in part because of the lack of a national constituency to serve as "watchdog." Desegregation in Yonkers, N.Y., presents a recent egregious example. See Note, The Legislative Injunction: A Remedy for Unconstitutional Legislative Inaction, 99 Yale L.J. 231, 243 (1989) [hereinafter Note, Legislative Injunction]. For an example from the prison context, see Note, "Mastering" Interiention in Prisons, 88 YALE L.J. 1062, 1067 (1979) [hereinafter Note, Prisons] ("The larger political community provides prison officials with little incentive to take the risks inherent in changing the current structure." (footnote omitted)).

27. 5 U.S.C. $\$ \$ 551-706(1988)$.

28. See generally P. Schuck, supra note 1, at chs. 1, 6 (reviewing organizational problems associated with bureaucracies). 
ficials may have an imperfect understanding of the agency's overall purpose or may have interests adverse to those of the institution. ${ }^{29}$ The result is that even though a bureaucrat may be quite efficient in performing his job, he fails to contribute meaningfully to the goals of the agency; in fact, his efforts may detract from its overall mission. ${ }^{30}$

The second source is the potential for misplaced economic incentives, which encourage to administrators to pursue strategies not compatible with the statutory and consensual framework within which the agency operates. $^{31}$ The fact that judges are positioned outside the bureaucratic framework enables them to help restructure bureaucratic incentives and policy when internal administrative policy contravenes constitutional requirements.

\section{The Role of Structural Reform}

Analysts of large-scale bureaucratic reform efforts paint different pictures of the role of the judge in structural reform. Professor Schuck advocates a multi-layered system of governmental liability which relies primarily on damages to correct official misconduct. ${ }^{32}$ Professor Fiss advocates a highly active role for the Federal bench, a role in which courts intervene with equitable remedies to implement community values. ${ }^{33}$ The new framework advanced below demonstrates how these two theories address different dimensions of the remedial decree: Schuck's prescription centers on furthering the perceived legitimacy of institutions, whereas Fiss' view concerns primarily the implementation of administrative remedies.

29. This phenomenon has been documented in a number of settings. See, e.g., Note, Prisons, supra note 26, at $1067 \&$ nn.27-28 ("Career guards or wardens may perceive [mandated] changes as a threat to their autonomy and security within the prison, and strongly resist efforts to alter established methods of operation."). Such resistance to change creates intransigence at both the operational and administrative levels. "To overcome resistance of old-line guards and powerful inmates, ... administrators may have to challenge their power in the prison, thereby promoting short-term disruptions such as guard walkouts or inmate boycotts ... . Such consequences may generate negative publicity and jeopardize the administrator's political career." Id. at 1067 n.28.

30. See P. Schuck, supra note 1, at 106-07 \& nn.16-17 (discussing incentives in bureaucratic institutions and listing additional sources of suboptimization).

31. A common theory suggests that the prime motivation for administrative behavior is the desire to accumulate the largest budget or other elements of administrative prestige or independence. See $\mathrm{W}$. Niskanen, Bureaucracy and Representative Government 42 (1971) ("Bureaucrats maximize the total budget of their bureau during their tenure, subject to the constraint that the budget must be equal to or greater than the minimum total costs of supplying the output expected by the bureau's sponsor.").

32. P. Schuck, supra note 1; see also Sunstein, Juaicial Relief and Public Tort Law (Book Review), 92 YALE L.J. 749-54 (1983) (discussing damages-based framework of Schuck's proposal). Schuck favors damage remedies for most reform efforts, as these are less intrusive forms of remedy than the structural decree. As Sunstein observes, Schuck "acknowledges that [injunctive] relief has considerable costs and ... taxes the institutional capacity of judges" but "argues that a structural decree can sometimes be 'legitimated' through a particular conception of its function." Id. at 753 .

33. See Fiss, supra note 18; see also O. Fiss, The Givil Rights Injunction (1978) (advocating use of injunction). 


\section{A. Existing Models of Structural Reform}

Professor Schuck insists on an institutionally limited role for the Federal judge. He sees the government as a complex of actors, each with some ability and authority to shape bureaucratic institutions in accordance with legal or policy-based prescriptions. The judge serves as only one of several governmental actors with the authority to reform bureaucratic entities and "competes" with other institutions in an effort to have her vision reflected in administrative policy. This "institutional competition"34 model suggests that the judge should recognize those reforms within her competence and political role. She then should select remedial steps which, while perhaps not capable of bringing institutions into perfect conformity with constitutional dictates without the cooperation of other political and administrative actors, will serve as a constitutional vision which may gain others' assent. $^{35}$ Varying levels of injunctive relief-including, as a last resort, the structural injunction-should be pursued only when less intrusive means fail.

In contrast, Fiss imagines a more court-centered role for structural reform and consequently conceives of the judge's function in more intrusive terms. His view, described as "judicial interpretivist," should reshape reality in the image of the rights that their constitutional interpretation requires. ${ }^{37}$ The province of the judge is not defined by a competitive process among governmental actors but by the judiciary's unique role in discerning and correcting constitutional infirmities. ${ }^{38} \mathrm{His}$ strong commitment to judicially-directed structural reform stems from his enthusiasm for court efforts to desegregate schools in the wake of Brown. ${ }^{39}$ A more confident advocate of the institutional capacity of the judge, Fiss is willing to overlook occasional instances of institutional limitation since the

34. P. Schuck, supra note 1 , at 178-81.

35. The scope of Professor Schuck's remedial system is large; indeed, he hopes that his framework for governmental liability extends to all types of governmental wrongs. His framework proposes "an expanded governmental liability for damages as its first and basic line of defense against public torts. ... [A] properly reformed governmental liability remedy would dominate official liability over the full range of public tort goals and constraints. Its scope would be greatly extended, covering all officially caused wrongs." Id. at 184 .

36. Id a t73-78. Fiss is concerned that "division of functions, a delegation of the task of actualization to another agency, necessarily creates the risk that the remedy may distort the right, and leave us with something less than the true meaning of the constitutional value." Fiss, supra note 18, at 53.

37. "The reconstructive endeavor, calling for instrumental judgments, should be seen . . . as but a necessary incident of that meaning-giving enterprise, as an attempt by the judge to give meaning to constitutional values in practical reality." Fiss, supra note 18, at 34.

38. Id. at 48 ("overriding mission of the structural decree is to remove the threat posed to constitutional values by the organization").

39. "As a genre of constitutional litigation, structural reform has its roots in the Warren Court era and the extraordinary effort to translate the rule of Brown $z$. Board of Education into practice." $I d$. at 2 (citation omitted); see also $\mathrm{O}$. FIss, supra note 33 (analyzing role of injunction during and after civil rights movement). A decade ago this led him to posit that "[s]tructural reform truly acknowledges the bureaucratic character of the modern state . . . and in the years ahead promises to become a central-maybe the central-mode of constitutional adjudication." Fiss, supra note 18, at 2. 
role of the court "is not to resolve disputes, but to give the proper meaning to our public values." 40

Schuck and Fiss also offer different remedial visions for structural reform. For Schuck, the remedial continuum is hierarchical, ${ }^{41}$ with the judge moving to more intrusive remedies only as the recalcitrance of the bureaucratic actors or the ineffectiveness of less intrusive remedies increases. ${ }^{42}$ Fiss, in contrast, believes that judges should not be so hesitant in remaking social institutions in the image of their perceived constitutional vision $^{43}$ and that intrusiveness should be a function of the severity of the constitutional infirmity.

While both Schuck and Fiss acknowledge that bureaucracy functions as an important provider in the administrative state, neither sees the role of the judge as defining the place of bureaucracy in the constitutional/regulatory system. Although Schuck offers to the judge a rich web of remedial devices as tools to "battle" bureaucracy, his reliance on damage remedies as the first and preferred solution to most cases of governmental wrongs rests on an economic assumption about bureaucratic behavior that cannot ensure street-level reform as efficiently as it can correct legitimacy shortcomings. ${ }^{44}$ Fiss, on the other hand, overestimates in some cases the institutional competence of the judge. Asking the judge to discern the contours of a right and then to reshape bureaucracy risks frustration when institutions have not internalized adequately the goals of the statutory/constitutional scheme. ${ }^{45}$ Simple damage remedies may be adequate in many cases where Fiss' model would suggest remaking the institution with complex equitable remedies. The model sketched below integrates these conceptions into a two-tiered view of administrative reform that reflects the judge's position in defining bureaucratic legitimacy and practice.

40. Id. at 30 .

41. P. ScHuck, supra note 1 , at 14, 20, 191-93.

42. Id. Such an emphasis on remedial restraint is explicit in Schuck's version of structural reform; while describing himself as "agnostic" toward the efficacy of the structural injunction, Schuck places such relief at the disfavored bottom of the remedial hierarchy, finding that judges must "swallow hard" before they pursue structural remedies. $I d$. at 184 .

43. Fiss" argument "place[s] adjudication on a moral plane with legislative and executive action." Fiss, supra note 18 , at 41 .

44. Schuck recognizes this; in fact, his suggestion to move liability from the individual officials implementing policy to the agency level reflects this concern about proper economic incentives. However, his remedial hierarchy becomes misleading because it does not give preference to the appropriate solution-intrusive equitable relief-when the institution's legitimagy is assured but reforms at the implementation level are still needed.

45. This suggests that the structural decree has evolved since its civil rights genesis. In the early days of desegregation efforts a judge's "heavy hand" no doubt was needed to reform entrenched racist attitudes. Today, however, the decree can be useful for reforming more benign (but nonetheless important) forms of bureaucratic misconduct, and the remedial process should be revised accordingly. 


\section{B. The Regulatory Model}

The judge attempts to perform two functions in reforming a regulatory body. First, the judge seeks to clarify, revise, or build consensus on the legitimacy of an institution by demarking its delegated powers more completely. Second, the judge seeks to ensure the implementation of reforms necessary for the delivery of mandated goods and services from the government to its citizens. ${ }^{48}$

This binary conceptualization defines more precisely than previous models the remedial role that the judge plays in restructuring a bureaucratic institution. The type of structural remedy the judge should pursue depends on which of two situations better characterizes the bureaucracy. First, when the agency's role is uncertain or confused in the constitutional or statutory scheme, an intrusive remedy is required to clarify this status. This involves encouraging legislatures and policy-making administrators to internalize the goals of constitutional or statutory mandates within the bureaucracy. ${ }^{47}$ Second, if the bureaucracy fails to carry out its defined mandate effectively, thereby denying citizens essential rights or services, judges should intervene with extensive equitable relief, directing mid- and street-level officials with detailed requirements that ensure the delivery of these services. This conceptual scheme places the concerns of Fiss and Schuck on different remedial planes, advocating an injunction-based structural decree as a primary tool of reform for implementation concerns while advocating a damages-based decree as more appropriate for legitimation concerns.

\section{Ensuring Policy-Level Legitimacy: Correcting Goals and Encour- aging Internalization of Objectives}

The goals and directives that governing bodies require an agency to pursue are frequently less than clear. The lack of clarity can come from conflicting statutory mandates, open-ended statutory grants of power that permit bureaucrats to exercise discretion at odds with other constitutional or statutory mandates, or from a simple lack of direction by the administrative authority. ${ }^{48}$ In seeking to legitimate bureaucratic structures, the

\footnotetext{
46. Professor Peters puts this distinction nicely: "Implementation is a central problem lof bureaucracy] in contemporary political systems. . . . While implementation is an important problem, . . . [a]t times there is a tendency to design programs for ease of implementation without asking whether that is really what governments want to do or should do." B. Peters, The Politics of BureauCRACY 186 (1984). Instead of attempting to define a role for courts in this process, however, Professor Peters overlooks the forward-looking nature of the structural injunction and concludes that the courts can serve only as "a negative check on bureaucracy." Id. at 259.

47. As argued below, damage remedies directed against these officials are generally the most effective way to accomplish this. See infra notes $48-50$ and accompanying text.

48. "[P]ublic law torts frequently involve standards that are abstract and open-ended. In constitutional litigation and in many cases involving regulatory provisions, it is often hard to speak in terms of the rule of law at all. The courts' role is not to apply rules laid down in advance, but to give content to public norms." Sunstein, supra note 32 , at 759-60.
} 
judge addresses at least three audiences. First, the judge may ask the legislature to speak more clearly about the purpose behind a bureaucratic agency. ${ }^{49}$ When the implementing legislation lacks the specificity that an agency requires to determine its regulatory mission, the court may spur the legislature to act to define the purpose and procedures of the bureaucratic entity.

Second, the judge may provide administrators with broad constitutional guidelines within which the agency must pursue its day-to-day operations, with the goal of forcing the bureaucracy to internalize the constitutional norm as part of its operating procedure. School administrators may be little inclined to accept constitutional requirements for school administration; the judge's task is not necessarily to prescribe specific remedial steps but to provide broad guidelines and adequate incentives for school administrators to take such concerns into account.

Third, the judge may address the community within which the bureaucracy operates. School boards, elected or appointed, generally reflect the will of the community, and the community's attitudes, in turn, help shape the attitudes of the board. By attempting to secure an understanding in the community of the constitutional imperative behind the decree, or at least to foster debate about the institution's goals, the judge enhances the bureaucracy's accountability to the community it serves.

When judges act to ensure the legitimacy of an agency's policies, they should not-perhaps cannot-hope to reform structures in terms of ideal constitutional visions. The purpose is to seek a definition of the bureaucratic structure that accommodates constitutional concerns; while a specific configuration of a desegregated school district might not be possible, a consensus (or, at least, an institutionalized goal) to desegregate in some way is. Success at the legitimacy level is defined by adoption of goals by relevant political institutions, not by implementation of a specific a priori vision of constitutional ends. ${ }^{50}$ This goal is more dialogue-dependent and accords more closely with Schuck's model: Political actors involved in determining the destiny of the bureaucracy barter and contribute their institutional say in defining the ends that the agency will pursue.

49. Cf. G. Calabresi, A Common Law for the AGe of Statutes (1982) (providing structure of mechanisms for courts to encourage dialogue with other governmental branches).

50. Professor Sunstein alludes to this function: "The aim [of structural decrees] . . . is to ensure that decisions are subject to public scrutiny and review. It is in this sense that the structural injunction can act as a surrogate for legislative control." Sunstein, supra note 32, at 761. This formulation appears to be a bit too broad. "Public participation" may be no more valuable in a structural decree than it is in everyday legislative decision-making, most of which does not interest the public. Instead, the importance of the decree lies in its ability to force the legislature to speak clearly about the goals of the bureaucracy and, in many cases, to harmonize these goals with constitutional or statutory mandates. 


\section{Ensuring Efficacy: Guaranteeing Compliance and Reform}

Bureaucracies may fail adequately to implement established policy directives for several reasons. First, the effects of sub-optimization and of insufficient economic incentives weaken mid- and street-level bureaucrats' adherence to policy goals. Second, effectiveness tends to decrease as bureaucratic authority diffuses. ${ }^{51}$ Third, administrators may attempt to meet accepted policy goals in ways different from those envisaged by political or judicial actors. ${ }^{62}$ Prisons provide an example: While the general goals of "incarceration within constitutional limits" may characterize administrators' goals, the means by which they implement these goals have diverged substantially from legislative or judicial notions..$^{53}$

To overcome these sources of resistance, a decree should contain specific, outcome-driven requirements. Sometimes this type of a decree will follow a judge's effort at achieving legitimacy within the institution. Reliable information on bureaucratic behavior is essential at this level, and judges today enjoy a variety of devices to assist with this. ${ }^{54}$

To summarize, on the implementation plane judges reform agency behavior to accord as closely as possible with judicial conceptions of constitutional mandates. The goals of the bureaucracy having been clarified, the

51. See B. PETERS, supra note 46, at 185 ("The necessity of mobilizing political support for policy, and its attendant need to bargain away some policy intentions of central government, may be fundamental to the political process when attempting to put legislation into effect.").

52. Professor Peters explains the dual nature of this misunderstanding:

Opposition to the policies of politicians is rarely overt, as this might violate the formal relationships between elective and permanent officials in government. More commonly, bureaucrats defeat politicians by obfuscation, delay, and the use of rules, regulations, and procedures. Politicians, being short-term occupants of their positions, rarely understand either the procedural mechanisms or the substance of policy as well as their nominal servants and consequently are frequently at the mercy of civil servants. Id. at 186 .

53. The case study of Arkansas prisons, see infra note 62, demonstrates this phenomenon. After six years of court oversight, the district court judge reported in his final decree that he did "not find any open or gross discrimination against black inmates. . . except to the extent that the maximum security cells are still segregated." Holt v. Hutto, 363 F. Supp. 194, 204 (E.D. Ark. 1973). Nonetheless, the judge remained "not at all sure that there is not some covert discrimination in the areas of classifications, job assignments, and punishments." Id.

54. For example, special masters can provide feedback to the judge and can monitor progress under the decree, and required reports from parties can inform the judge of the success or failure of officials in carrying out prescribed policy. The Holt case, see infra note 62 and accompanying text, again provides an example.

Commissioner Sarver commented that, when the Holt litigation began, the judge's knowledge of prisons and prison life was "unsophisticated." The growth of his knowledge about corrections was illustrated by the comments of Commissioner Hutto and his staff that the judge understood correctional problems, was familiar with correctional terminology, and that his orders, suggestions, and recommendations were consistent with sound correctional policies.

Nat'l InST. of Law Enforcement and CRIMinal Justice, Law Enforcement ASSistance Admin., U.S. Dep'T of Justice, After Decision: Implementation of Judicial Decrees in Correctional Settings 92 (1977) (footnotes omitted) (authored by M. Harris \& D. Spiller) [hereinafter M. HaRris \& D. SPILLER]. Fiss does not think that "there is some special bady of knowledge relevant for . . . remedial undertaking, but even if there were, it still remains to be seen why it could not be made available to the judge, either through expert witnesses, or through auxiliary structures such as special masters." Fiss, supra note 18 , at 34. 
judge seeks to reform the outcome of the bureaucratic process to reflect the mandates of the Constitution. ${ }^{\mathrm{s}}$

\section{Implications of the Model}

Two implications can be derived from the model. First, damages serve as the primary remedy for legitimation goals, whereas equitable relief is more useful for implementation. Damages, by encouraging bureaucratic actors to come to court or to deal with court-imposed sanctions-appealing the decision to a higher court, holding debates about the implications of the damage award, and realizing the impact that fines and compensatory awards will have on taxes and budgets-often encourage political soul-searching and institutional redefinition, which results in clarified goals for the affected agency. ${ }^{56}$ Legislatures are forced to deal with fines and damages in the appropriations process; administrators face budget constraints; citizens feel the pinch in tax assessments. These pressures encourage widespread consideration of how the bureaucracy effects the changes required by the judge's decree.

Second, the judge's focus in a decree may change over time, encouraging her to place greater emphasis on implementation devices as adverse bureaucratic practices become more entrenched. In the years immediately following a bureaucracy's establishment, the judiciary may find occasional corrections and clarifications of goals of primary importance. Institutional rigidities may thereafter develop, requiring the judge to focus more on the efficacy of the institution's operation than on clarification of its goals. New judicial information-gathering and enforcement devices have extended the power of the court to guarantee that its decrees are implemented. ${ }^{57}$ Declaration of the complete contour of a right is not needed at the trial because further investigation and reporting can inform the judge's decisions about the types of reform that are needed and how they can be implemented incrementally. In addition, defendant bureaucracies have found it in their interest to discuss potential solutions with plaintiffs, and judges, through devices such as the special master, have encouraged such negotiation. ${ }^{58}$ In short, the structural injunction encourages us to stop

55. Fiss states the goal clearly (if somewhat broadly): "The desire to be efficacious need not be seen as an assertion of will, but as a willingness of the judge to assume responsibility for practical reality and its consonance with the Constitution." Fiss, supra note 18 , at 58 .

56. The Yonkers case provides an excellent example. Judge Sand was unable to obtain a high level of compliance by specifying steps that the city should take to remedy housing and segregation problems. But when specific fines were imposed against the recalcitrant city council, the community and its leaders engaged in discussion, resistance, and debate in the process of defining the purpose of the city's school and housing policies. See Chicago Trib., Mar. 13, 1990, at 8 (Yonkers school desegregation proceeded as city council members fought Federal court battle); N.Y. Times, Jan. 21, 1990, $\S$ 12 (Westchester), at 1, col. 5 (slow progress on housing desegregation; recent positive steps occurring despite council's continued resistance).

57. See supra note 54 and accompanying text.

58. See Note, Force and Will: An Exploration of the Use of Special Masters to Implement Judi- 
thinking of the judge in the historical, "rights-declaring" framework and to view the decree as an important element of the regulatory landscape in which judges foster the evolution and enforcement of rights in bureaucratic settings.

\section{Case Studies of Structural Reform}

\section{A. Varieties of Structural Reform}

Although the legitimacy-implementation dichotomy is not a precise categorization $^{58}$ and each structural reform has a large number of distinctive characteristics, structural decrees can be arrayed according to their primary reform purposes. The following descriptions show how structural reorderings can be classified along the model's two dimensions.

School Boards. Reforming school board practices generally involves reorientation of the board's community role, followed by specific instructions as to how these goals are to be pursued. Desegregation's goals are typically hotly disputed. Judges need to convince other political actors of the legitimacy of goals at least as much as they need to implement the desired reform. These goals are decidedly political; while specific implementation steps are components of desegregation decrees, the major focus of most desegregation efforts is on convincing community and political actors of the value of a desegregated educational environment or of equalization of educational opportunities between students of different races. Presumably, if this battle were won, implementation would become a much more manageable task.

Mental Hospital Administration. ${ }^{60}$ In mental hospital reform, judges typically face institutions with medium or low legitimacy needs and high implementation needs. General consensus exists as to the goal of the institution-assistance for mentally disturbed individuals ${ }^{61}$-but the policy ve-

cial Decreps, 52 U. Colo. L. Rev. 105 (1980) (describing use of special masters in complex decrees); Note, Prisons, supra note 26 (analyzing role of master in five field settings).

59. Furthermore, characterizing a decree as largely legitimizing or implementing will change over time. Once the legitimizing function is fulfilled-whether by damages or other means-the court can shift its attention toward implementation of the consensual value through the bureaucracy. In some instances both goals may be pursued within the same decree, but establishment of legitimacy is always a prerequisite for effective implementation of policy.

60. A classic example of this type of public litigation is Wyatt v. Stickney, 344 F. Supp. 373, 344 F. Supp. 387 (M.D. Ala. 1972), enforcing 325 F. Supp. 781, 334 F. Supp. 1341 (M.D. Ala. 1971), affd in part, remanded in part, decision reserved in part sub nom. Wyatt v. Aderholt, 503 F.2d 1305 (5th Cir. 1974). "[This case] has all the elements of a dramatic set piece: wretched mental patients, a steely-eyed judge of national prominence, a recalcitrant state bureaucracy, and a new constitutional right." Eisenberg \& Yeazell, The Ordinary and the Extraordinary in Institutional Litigation, 93 Harv. L. Rev. 465, 468 (1980) (footnote omitted). Despite the bitter encounter between judge and bureaucracy, the general consensus that existed behind the judge's efforts made success more likely.

61. This does not imply that all questions of administration have been solved. Indeed, within the mental health field, debates over rehabilitation methods abound. In assessing the legitimacy of an institution, courts are generally concerned only with the broader issues of general institutional priorities. 
hicles used to achieve this goal are little understood. Judges' efforts in such cases are devoted predominantly toward analyzing the best way to provide appropriate care for institutionalized persons. This implies that damage remedies are less useful for achieving reform of the bureaucracy than would be specific instructions to hospital administrators as to how to make changes.

Prison Administration. Typically, legitimacy needs may need to be clarified at certain points, but the bulk of the judge's efforts are not, as in the case of school boards, spent convincing administrators of these goals but in seeking ways to compel them to reform in light of accepted broad constraints on incarceration. The institutional function is largely agreed upon-incarceration. The judge's efforts are devoted almost completely to implementation of the goal in the context of constitutional guarantees. Consensus-building takes place on the largely non-ideological planes of funding levels, staff provisions, and related matters.

\section{B. Two Case Studies of Structural Reform}

Two instances of structural reform illustrate the nuances of the reform process and the different results that the judge is likely to undertake in reform efforts. In the first, Judge Henley of the Eastern District of Arkansas (and later of the Eighth Circuit Court of Appeals) ordered reform of the Arkansas prison system. ${ }^{62}$ Holt $I$ initiated the decree and held that

62. Citation of the many elements of a structural injunction is sometimes difficult. The primary decisions in the Arkansas prison reform are as follows: Talley v. Stephens, 247 F. Supp. 683 (E.D. Ark. 1965) (prisoners entitled to procedural checks on corporal punishment, unencumbered access to court, and other benefits); Jackson v. Bishop, 268 F. Supp. 804 (E.D. Ark. 1967) (enjoining use of leather "strap" for corporal punishment as violative of cruel and unusual punishment clause until adequate procedural safeguards established), vacated and reinanded, 404 F.2d 571 (8th Cir. 1968) (holding any use of leather "strap" to be cruel and unusual punishment and enjoining any corporal punishment); Courtney v. Bishop, 409 F.2d 1185 (8th Cir. 1969) (affirming district court's finding that conditions surrounding solitary confinement do not constitute cruel and unusual punishment); Holt v. Sarver, 300 F. Supp. 825 (E.D. Ark. 1969) (Holt I) (first stage of structural decree) (finding supervision and sanitary conditions in prison violative of prisoners' constitutional rights and requiring officials to improve conditions); Holt v. Sarver, 309 F. Supp. 362 (E.D. Ark. 1970) (Holt II) (primary structural decree) (enjoining unconstitutional infliction of cruel and unusual punishment by means of "trusty" guard system, open barracks, isolation cell conditions, and absence of rehabilitation program; suit, instead of contemplating piecemeal reforms, "amounts to attack on the system itself"), aff $d, 442$ F.2d 304 (8th Cir. 1971); Holt v. Hutto, 363 F. Supp. 194, 198 (E.D. Ark. 1973) (Holt III) (finding some improvement in prison conditions but requiring many more specific reforms and finding "respondents need to be admonished about a number of things"); Finney v. Arkansas Bd. of Corrections, 505 F.2d 194 (8th Gir. 1974) (finding more constitutional requirements and commanding Judge Henley to retain jurisdiction), reh'g denied, 505 F.2d 194, 215 (1974); Finney v. Hutto, 410 F. Supp. 251 (E.D. Ark. 1976) (finding medical care, certain disciplinary procedures, and living conditions to violate Constitution and awarding attorneys fees and certain costs), aff d, 548 F.2d 740 (8th Cir. 1977) (affirming unconstitutionality of 30 days' punitive isolation; affirming grant of attorneys fees), aff $d$, 437 U.S. 678 (1978) (commending entire reform effort). A consent decree was signed on October 5, 1978, but this did not end the court proceedings. See Finney v. Mabry, 534 F. Supp. 1026 (E.D. Ark. 1982) (finding non-compliance with certain consent decree requirements and prior orders); Finney v. Mabry, 546 F. Supp. 626 (E.D. Ark. 1982) (containing additional specific reforms to be implemented); Finney v. Mabry, 546 F. Supp. 628 (E.D. Ark. 1982) (compliance with consent decree found; case dismissed). Excerpts of the primary opinions appear in O. FIss \& D. RENDLEMaN, IN- 
prisoners' constitutional rights demanded improved sanitary conditions and better supervisory procedures. Holt II, by enjoining cruel and unusual punishment in a variety of forms, was an important declaration of prisoners' rights and called for several specific prison reforms. Holt III specified further constitutional violations, such as racial and religious discrimination and undue mail restrictions. Judge Henley's efforts resulted in muchimproved conditions in Arkansas prisons and establishment of future protections for prisoners' rights.

In the second case, Judge J. Skelly Wright supervised the attempted equalization of resource distribution in the segregated District of Columbia public schools. ${ }^{63}$ Hobson $I$, an exhaustive analysis of school segregation in the District of Columbia and of constitutional law governing school systems, contained the principal decree, the essence of which was "[a]n injunction against racial and economic discrimination in the public school system." ${ }^{64}$ Hobson II refined the decree to include a requirement of equalized teacher resource expenditures among schools. While most reviews acknowledge that Judge Wright did not experience the success originally anticipated, ${ }^{65}$ his efforts represented an important attempt to realize the promise of Brown in a severely segregated public school district.

\section{The Implementation Dimension}

Both reform decrees enjoyed at least some success in implementation. As discussed below, however, only the prison reform enjoyed the consensus over institutional legitimacy which was required for the decree to function effectively. Judge Henley declared in Holt $I$ that prison conditions denied prisoners their constitutional rights, and he established property rights for prisoners in the reforms ordered by the injunction. ${ }^{66}$ Judge Henley expanded the base of prisoners' constitutional rights in Holt II

JUNCTIONS 529-752 (2d ed. 1984). See also Eisenberg \& Yeazell, supra note 60, at 470-73 \& nn.23-50 (describing Holt litigation and listing commentary on cases).

63. Hobson v. Hansen, 265 F. Supp. 902 (D.D.C. 1967) (upholding constitutionality of congressional grant to judges of power to appoint D.C. school board members), appeal dismissed, 393 U.S. 801 (1968); Hobson v. Hansen, 269 F. Supp. 401 (D.D.C. 1967) (Hobson I) (primary decree; enjoining unequal resource distribution among D.C. pupils), aff $s u b$ nom. Smuck v. Hobson, 408 F.2d 175 (D.C. Cir. 1969); Hobson v. Hansen, 320 F. Supp. 409 (D.D.C. 1970), 320 F. Supp. 720, 327 F. Supp. 844 (D.D.C. 1971) (Hobson II) (narrowing decree to required equalization of expenditure on teachers among schools). For a thorough review of the Hobson proceedings, see D. HorowrT, supra note 9, at 106-70.

64. Hobsom I, 269 F. Supp. at 407.

65. Set, t.g., D. HoRowirz, supra note 9, at 264 (noting "impotence of the courts to supervise the implementation of their decrees" and other inherent limitations on courts' administrative capabilities); of. P. Schuck, supra note 1, at 154-55 (reviews of structural reforms mostly negative, but "[i]n truth . . . the success of structural injunctions in implementing substantive rights probably cannot accurately be assessed").

66. The court stated, "[I]f the State, acting through its penal authorities, is depriving convicts of rights which the Constitution protects . . . the Court may and should intervene to protect those rights and to put an end to unconstitutional practices." $300 \mathrm{~F}$. Supp. at 827. 
and Holt III ${ }^{67}$ broadening the rights declared in Holt I to include a general constitutional right to improved prison conditions. ${ }^{68}$ To ensure compliance, Judge Henley utilized information-gathering and monitoring systems to apprise him of the reforms that the defendants made. ${ }^{6 \theta}$ Since the judge recognized the potential problems with attempts to establish restrictive decrees that would bind correctional officials, he permitted a degree of flexibility in implementing the mandate. ${ }^{70}$ Through these and subsequent decrees, the judge placed specific responsibilities on prison officials, expanding and contracting their discretion with respect to court directives in accordance with their progress in respecting constitutional rights. ${ }^{71}$ The judge's understanding of the political structure of the prison system and of its connection to governing political institutions explains the high degree of success achieved in the decree.

In Hobson, Judge Wright attempted to sculpt his decree to require specific reforms. Offending school board practices included a policy permitting white students to transfer to predominantly white schools on a relatively easy showing that integration caused them "psychological upset"; a gerrymandering of school boundaries for racial purposes, including the

67. Holt II, "unlike earlier cases . . . which have involved specific practices and abuses alleged to have been practiced upon Arkansas convicts, amount[ed] to an attack on the System itself." 309 F. Supp. at 365. Judge Henley emphasized the magnitude of the action. "As far as the Court is aware, this is the first time that convicts have attacked an entire penitentiary system in any court, either State or federal." Id; see also id. at 373 (describing case as assessing whether "overall conditions" constitute cruel and unusual punishment).

68. "[T]he Court will declare that to the extent indicated heretofore confinement in the Arkansas Penitentiary System under existing conditions amounts to a cruel and unusual punishment constitutionally prohibited." Id. at 382; see alsa id. at 365 (sustaining petitioners' claim that confinement of persons in penitentiary system amounts to cruel and unusual punishment prohibited by Eighth and Fourteenth Amendments); $i d$. at 381 (reaffirming that racial discrimination in prisons violates Fourteenth $A$ mendment). Specific reforms guaranteed included dismantling the "trusty" guard system, improving supervision in the barracks, and improving sanitary and eating conditions in isolation cells. Id. at 384-85.

69. The court required compliance reports from defendants and held four compliance hearings. Prison inspections, plaintiffs' attorneys, and inmate correspondence and petitions apprised the court of action not taken by defendants. "The monitoring mechanisms employed by the court appeared to be highly effective both in apprising the court of the defendants' compliance progress and as a positive factor contributing to the level of compliance that was achieved." M. HARRIS \& D. SPILlER, supra note 54 , at 106.

70. 300 F. Supp. at 833 (Court unwilling to prescribe any specific immediate steps); 309 F. Supp. at 383 ("Respondents should be given an opportunity to come forward with a plan ....").

71. "[Judge Henley] acknowledged that the nature of individual cases might dictate different approaches. In his opinion, lawsuits that involved extremely bad conditions demanded swift remedial action. Similarly, if prison administrators resisted court-ordered changes, the court would be forced to issue highly specific orders." M. HARRis \& D. SPILLER, supra note 54, at 88-89.

Furthermore, "Judge Henley threatened the imposition of sanctions (in the form of dismissing correctional employees, imposition of contempt penalties and closure of prison facilities) for failure to comply with court orders." Id. at 91 . His opinion stated:

The Court does not now foresee that circumstances will arise which would require the Court to impose the ultimate sanction available to it, that of closing one or both of the prisons or enjoining the further reception of inmates at one or both institutions. Less rigorous, but effective, sanctions are available. The Court can direct the discharge of offending employees; the Court can punish for contempt, and it can award attorney's fees and expenses of litigation. Holt III, 363 F. Supp. at 217. 
use of "optional zones" which permitted white students a choice of schools where the neighborhood school was predominantly black; and segregation of teachers and principals, largely along racial lines. ${ }^{72}$ In Hobson I, Judge Wright declared that the plaintiffs should be afforded the right to equal resources such that to the greatest possible extent black and white students received equal educational opportunity ${ }^{73}$ Despite this basic motivation, equalization of resources did not occur. Few students were integrated, teachers did not relocate to produce integrated faculties, and expenditures on teacher resources in primarily white schools remained about ten percent higher than in primarily black schools. ${ }^{74}$

In Hobson II, instead of requiring the board explicitly to equalize pupil expenditures, ${ }^{75}$ Judge Wright narrowed the scope of relief by using the proxy of equalization of expenditures for teachers, ${ }^{76}$ a basis the judge used to measure discriminatory effects. ${ }^{77}$ Coming in the wake of Brown, the Hobson decree was Judge Wright's attempt to seek broad change in a politically charged environment. ${ }^{78}$ Structural barriers hardened and proved frustrating as the court attempted to mandate large-scale change in a relatively short period of time without the institutional consensus required.

\section{The Legitimacy Dimension}

In the prison litigation, Judge Henley achieved a fair amount of support and consensus among decision-makers in other areas of the government. Although Judge Henley did need to overcome certain political obstacles, he did not confront paralyzing resistance from non-prison officials to his vision of the constitutionally minimal conditions of incarceration.

Other members of the establishment responsible for the legitimacy of the prison and its policies may not have shared the vision of the constitutional rights that Judge Henley sought to provide the prisoners; that the

72. 269 F. Supp. at 406-07, 415-19, 499-501, 501-03.

73. "II]f whites and Negroes, or rich and poor, are to be consigned to separate schools, pursuant to whatever policy, the minimum the Constitution will require and guarantee is that for their objectively measurable aspects these schools be run on the basis of real equality, at least unless any inequalities are adequately justified." $I d$. at 496.

74. A commentator remarks that "these measures had no discernible impact on the allocation of school resources." D. HoRowrTz, supra note 9, at 117.

75. 327 F. Supp. at 861-64 ("the court does find that the equalization order approach is a good one").

76. Id. at $863-64$ (requiring not more than five percent deviation in teachers' salaries and benefits across schools).

77. "Unrebutted and unjustified, the prima facie case of racial discrimination ripened into a firm finding and the resulting equalization [of teacher expenditure] order." D. Horowirz, supra note 9, at 120 .

78 Because of these teachers' fungibility, the district was able to equalize expenditures without much change in the resources generally available to the students. In addition, school principals could thwart the court's decree by engaging in action to protect their teachers and resources, usually by soliciting additional funding from organizations such as the P.T.A. and from foundations, and by inventing reasons for harboring more students in the school, such as the creation of a new grade level. 
legislators and executive had failed to act on news of the prison's deplorable conditions is perhaps indicative of their attitude. But this does not imply that consensus about the institution's legitimacy was at issue. Seeking consensus on bureaucratic purpose does not require convincing other actors of the specific reforms that the judge would like to implement. These reforms are, as Fiss argues, peculiarly the province of the judge. ${ }^{79}$ To achieve these reforms, the judge must first either have agreement within the community about the role that the bureaucracy plays or seek to shape such consensus.

Judge Wright failed in this respect. Directing most of his energy to the "street-level" reform of the specific school board policy, he neglected to induce agreement surrounding the role that the school board should play in the community life of Washington, D.G. Mobile political forces and entrenched administrative interests at all levels worked to thwart his efforts. The judge might have experienced greater success by first fining or imposing damages on the governmental figures responsible for the community policy (or on the community itself), ${ }^{80}$ with a view toward bringing the disparate interest groups to recognize the necessary fundamental benefits from desegregation's reordering of the community.

\section{CONCLUSION}

The structural decree plays a dual role in institutional litigation. The two conditions of structural reform-legitimacy and implementation-must be met for reform to be successful. Disaggregating the purposes of the decree and understanding the need to tailor the remedy appropriately provide a conception of public law litigation that explains judges' successes and failures in reform efforts. Furthermore, the model responds to, and incorporates, the insights of the remedy's proponents-the judge serves as interpreter of our constitutional values while also achieving reforms at the policy level. Not to recognize these two roles risks reshaping structural litigation on narrower grounds, which would deprive courts and citizens of an important means of protecting constitutional and statutory values in the bureaucratic state.

\footnotetext{
79. See supra note 18 and accompanying text.

80. For an argument that the judiciary can legitimately mandate specific actions by legislators, see Note, Legislatite Injunction, supra note 26.
} 